\title{
Phase Equilibria of Three Binary Mixtures: Methanethiol + Methane, Methanethiol + Nitrogen, and Methanethiol + Carbon Dioxide
}

\author{
Awan, Javeed; Tsivintzelis, loannis; Coquelet, Christophe; Kontogeorgis, Georgios
}

Published in:

Journal of Chemical and Engineering Data

Link to article, DOI:

10.1021/je2011049

Publication date:

2012

Document Version

Publisher's PDF, also known as Version of record

Link back to DTU Orbit

Citation (APA):

Awan, J., Tsivintzelis, I., Coquelet, C., \& Kontogeorgis, G. (2012). Phase Equilibria of Three Binary Mixtures:

Methanethiol + Methane, Methanethiol + Nitrogen, and Methanethiol + Carbon Dioxide. Journal of Chemical and Engineering Data, 57, 896-901. https://doi.org/10.1021/je2011049

\section{General rights}

Copyright and moral rights for the publications made accessible in the public portal are retained by the authors and/or other copyright owners and it is a condition of accessing publications that users recognise and abide by the legal requirements associated with these rights.

- Users may download and print one copy of any publication from the public portal for the purpose of private study or research.

- You may not further distribute the material or use it for any profit-making activity or commercial gain

- You may freely distribute the URL identifying the publication in the public portal 


\title{
Phase Equilibria of Three Binary Mixtures: Methanethiol + Methane, Methanethiol + Nitrogen, and Methanethiol + Carbon Dioxide
}

\author{
Javeed A. Awan, ${ }^{\dagger}$ Ioannis Tsivintzelis, ${ }^{\dagger}$ Christophe Coquelet, ${ }^{\ddagger}$ and Georgios M. Kontogeorgis ${ }^{*}{ }^{\dagger}$ \\ ${ }^{\dagger}$ Center for Energy Resources Engineering, Department of Chemical and Biochemical Engineering, Technical University of Denmark, \\ Building 229, DK-2800 Kgs. Lyngby, Denmark \\ ${ }^{\ddagger}$ MINES ParisTech, CEP/TEP - Centre Énergétique et Procédés, 35 Rue Saint Honoré, 77305 Fontainebleau, France
}

\begin{abstract}
New vapor-liquid equilibrium (VLE) data for methanethiol (MM) + methane $\left(\mathrm{CH}_{4}\right)$, methanethiol $(\mathrm{MM})+$ nitrogen $\left(\mathrm{N}_{2}\right)$, and methanethiol $(\mathrm{MM})+$ carbon dioxide $\left(\mathrm{CO}_{2}\right)$ is reported for temperatures of $(304,334$, and 364$) \mathrm{K}$ in the pressure range ( 1 to 8 ) $\mathrm{MPa}$. A "static-analytic" method was used for performing the measurements. The objective is to provide experimental VLE data for methanethiol with other natural gas contents at its crude form, for which no data are available in the open literature. The new VLE data for the aforementioned systems have been modeled successfully with the cubic-plus-association equation of state (CPA EoS).
\end{abstract}

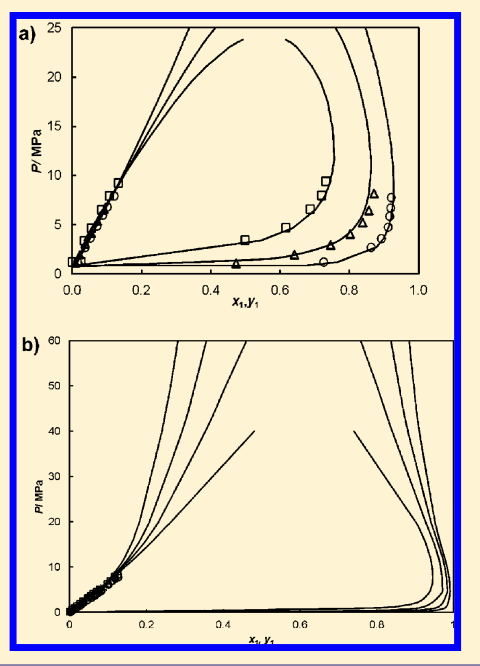

\section{INTRODUCTION}

Interest in the phase behavior of systems containing low molecular weight thiols (mercaptans) like methanethiol and ethanethiol is based upon the fact that they are present in varying concentrations in natural gas, crude oil, and petroleum products. Because thiols contain sulfur, have a distinct odor, and may freeze out in natural gas liquefaction. The knowledge of their properties and characteristics of their mixtures with hydrocarbons is important to both process design and to product specifications. ${ }^{1}$ In the oil and gas processing industry, the necessity to model the distribution of the thiols between various streams containing light hydrocarbons, $\mathrm{CO}_{2}$, and $\mathrm{N}_{2}$ increases the demand of such a kind of data. Unfortunately limited or no information is available in the literature for the phase behavior of such kinds of mixtures.

Carroll and Mather ${ }^{2}$ presented a literature review of available experimental data for natural gas systems containing the light hydrocarbons; methane through $n$-hexane, light thiols; and methanethiol through butanethiol and several inorganic compounds found in natural gas (nitrogen, carbon dioxide, and hydrogen sulfide). The authors conclude that there exist only a few data for methanethiol $+\mathrm{H}_{2} \mathrm{~S}$ and no data are available in literature for methanethiol $+\mathrm{N}_{2}$ and methanethiol $+\mathrm{CO}_{2}$ systems.

Plenty of data for the solubility of $\mathrm{CO}_{2}$ and $\mathrm{H}_{2} \mathrm{~S}$ in water and other solvents exist, but limited information about the solubility of thiols is available in the open literature (Huttenhuis et al.). ${ }^{3}$ Our study of the literature revealed no data for systems containing thiols $+\mathrm{N}_{2}$ and thiols $+\mathrm{CO}_{2}$. This represents a significant void in the available database. ${ }^{2,4,5}$ To serve the development of a database for such compounds and to enhance better thermodynamic modeling, new vapor-liquid equilibrium data of three binary systems containing $\mathrm{CH}_{3} \mathrm{SH}+\mathrm{CH}_{4}, \mathrm{CH}_{3} \mathrm{SH}+$ $\mathrm{N}_{2}$, and $\mathrm{CH}_{3} \mathrm{SH}+\mathrm{CO}_{2}$ at three different temperatures, (304, 334 , and 364 ) $\mathrm{K}$, with a pressure variation from (1 to 8) $\mathrm{MPa}$ are reported in this work. The capability of the cubic-plusassociation equation of state (CPA EoS; Soave-RedlichKwong, SRK, functionality) is further tested for the representation of the phase behavior of such binary systems.

\section{EXPERIMENTAL SECTION}

Purities and suppliers of materials are presented in Table 1 . No further purifications of the chemicals were made.

Table 1. CAS Numbers, Purities, and Suppliers of Materials

\begin{tabular}{llcl}
\multicolumn{1}{c}{ chemical name } & CAS no. & mass fraction purity & \multicolumn{1}{c}{ supplier } \\
methanethiol $\left(\mathrm{CH}_{3} \mathrm{SH}\right)$ & $74-93-1$ & $\geq 0.98$ & Acros \\
nitrogen $\left(\mathrm{N}_{2}\right)$ & $7727-37-9$ & 0.99 & Air Liquide \\
carbon dioxide $\left(\mathrm{CO}_{2}\right)$ & $124-38-9$ & $\geq 0.99$ & Air Liquide \\
methane $\left(\mathrm{CH}_{4}\right)$ & $74-82-8$ & $\geq 0.99$ & Messer \\
\hline
\end{tabular}

The experimental work has been carried out at CEP-TEP (Centre Énergétique et Procédés), MINES ParisTech, France,

Received: October 26, 2011

Accepted: January 13, 2012

Published: February 3, 2012 


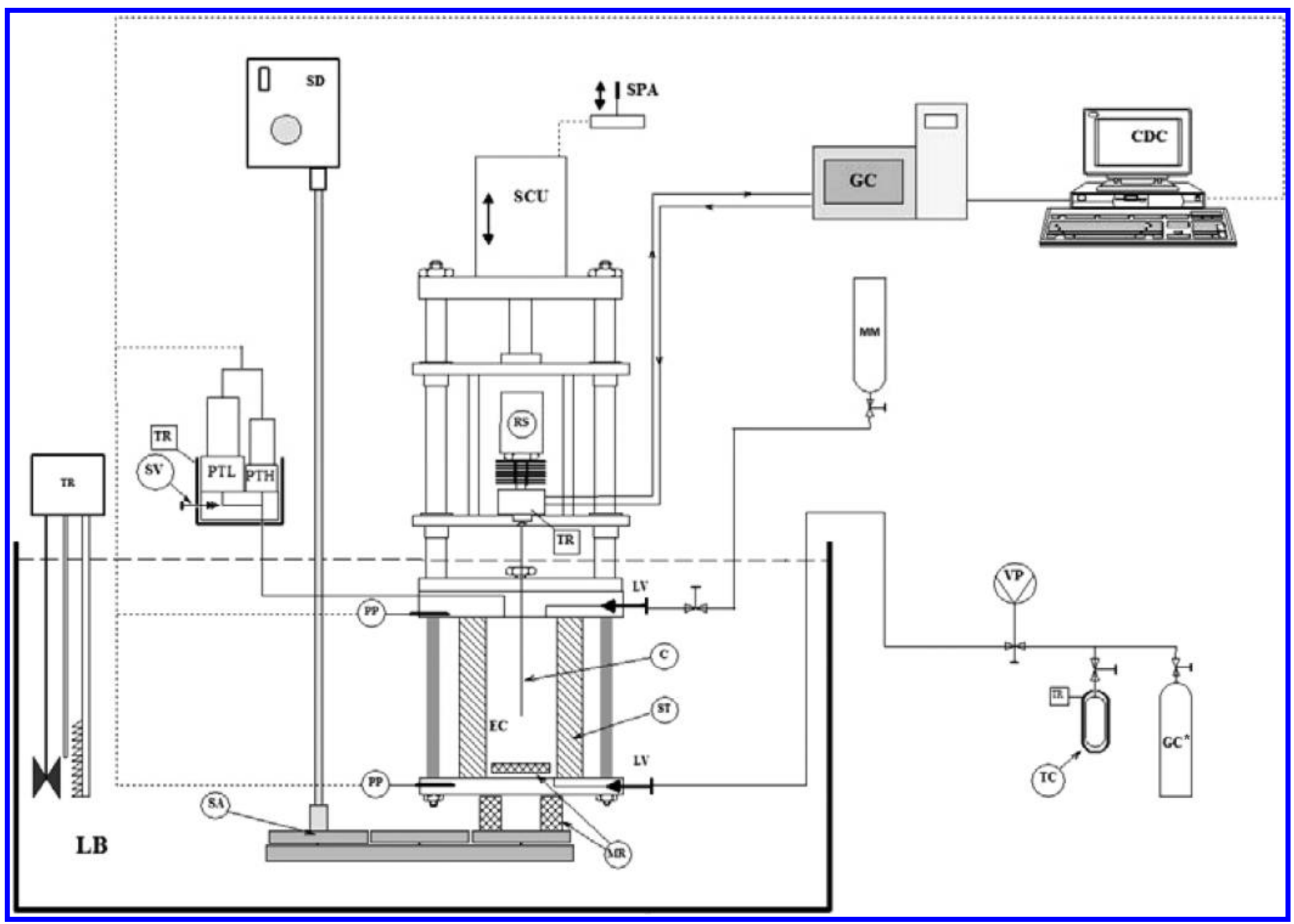

Figure 1. Static-analytic vapor-liquid-liquid equilibrium (VLLE) setup with a mobile capillary sampler. Descriptions: C, capillary; CDC, central desktop computer; EC, equilibrium cell; GC, gas chromatograph; LB, liquid bath; LV, loading valve; MM, methanethiol cylinder; PP, platinum temperature sensor; PTH, high pressure transducer; PTL, low pressure transducer; RS, phase sampler ROLSI; SCU, dampler control unit; SM, stirring device (motor); SPA, sampler position adjustment joy stick; ST, sapphire tube; SV, separating valve; TC, temperature controller; TR, thermal regulator; VP, vacuum pump; $\mathrm{GC}^{*}$, gas cylinder.

where a "static-analytic" technique based apparatus consisting of an equilibrium cell equipped with one moveable rapid online sampler injector (ROLSI) was used. The equipment is identical to the one used by Zehioua et al., ${ }^{6}$ and the procedure is identical to Coquelet et al. ${ }^{7}$ The ROLSI sampler is capable of making vapor-liquid samples without disturbing the equilibrium concentration and pressure, since the size of the samples (less than $1 \mu \mathrm{L}$ ) is negligible compared to the volume of the cell, that is, $20 \mathrm{~cm}^{3}$. The liquid and vapor samples are analyzed using a gas chromatograph (Varian model CP-3800), equipped with a thermal conductivity detector (TCD), and a flame ionization detector (FID). The schematic diagram is shown in Figure 1.

The sampling chamber of the online sampler is connected to a GC (Varian model CP-3800) through its injector and column in such a way that the carrier gas (helium) is circulated through the analytical circuit. The sample is transferred from equilibrium cell to the sampling chamber because of positive pressure difference between them. The pressure is kept constant inside the analytical circuit around $300 \mathrm{kPa}$. ROLSI sampler is heated in order to vaporize the sample. The transfer line between the ROLSI sampler and the gas chromatograph is heated to avoid condensation of the sample. Herein a thermal conductivity detector (TCD) and a flame ionization detector (FID) are used for analyses.

The operation of the online sampler is quite easy. The electromagnet moves the plunger for a back-and-forth stroke for an adjustable period of time. The carrier gas is continuously circulated through the ROLSI. The sample transfer lines have special arrangements to ensure that the mixture of the sample and carrier gas does not absorb, get trapped, or have partial condensation inside the analytical line: the transfer line is internally coated by inert silica. The sampler has the possibility of controlling the sample size (few $\mu \mathrm{L}$ ) by adjusting the aperture opening time. The sampling position inside the equilibrium cell can be adjusted by using a suitable assembly to move the capillary of the sampler up and down inside the equilibrium cell.

Two $100 \Omega$ platinum probes (Pt100) were used for temperature measurements, as shown in Figure 1. They were periodically calibrated against a $25 \Omega$ reference platinum resistance thermometer (TINSLEY precision instruments, France). The resulting accuracy in temperature measurements was estimated to be within $\pm 0.04 \mathrm{~K}$. Pressures were measured by means of a Druck pressure transducer (0.1 to 10$) \mathrm{MPa}$, which was maintained at $353.15 \mathrm{~K}$. Pressure and temperature were 
continuously recorded through a HP34970A data acquisition unit. This online data acquisition unit was connected to a personal computer through one RS-232 interface, which allowed real time readings and storage of data throughout the experimental procedure.

The pressure transducers were calibrated against a deadweight pressure balance (Desgranges \& Huot 5202S, CP (0.3 to 40) $\mathrm{MPa}$, Aubervilliers, France). Accuracies in pressure measurements have been estimated to be within $\pm 0.003 \mathrm{MPa}$. The gas chromatograph detectors were calibrated using chromatographic syringes with maximum mole numbers uncertainties of $2 \%$ in the TCD and $1.5 \%$ in the FID.

In all of the experiments at first, methanethiol was loaded to the equilibrium cell in the absence of air. $\mathrm{CH}_{4}, \mathrm{CO}_{2}$, or $\mathrm{N}_{2}$ were added to reach the desired pressure. The required temperature was obtained by putting the cell into a thermoregulated oil bath. Once the temperature and pressure were constant for a specific inlet concentration, the vapor and liquid samples from equilibrium cell were directly introduced to gas chromatograph through the isothermal transfer line. The gas chromatograph generates peaks of the individual components of $\mathrm{CH}_{4}$ (FID), $\mathrm{CH}_{3} \mathrm{SH}$ (FID), $\mathrm{CO}_{2}$ (TCD), and $\mathrm{N}_{2}$ (TCD) at specific retention times. The area under such peaks corresponds to the number of moles of the individual components, which come from the corresponding calibration.

The standard deviation on each experimental datum $\left(\sigma^{\mathrm{A}}\right)$ is calculated and presented along with data. The method for the calculation of standard deviation on experimental data $\left(\sigma^{\mathrm{A}}\right)$ is reported in our previous article. ${ }^{8}$

The standard deviation which comes from the experimental value can be written as

$$
\sigma^{\mathrm{A}}=\frac{1}{x^{*}} \sqrt{\frac{\sum\left(x-x^{*}\right)^{2}}{n-1}}
$$

where $x$ is the measured value, $x^{*}$ is the average of the measured values, and $n$ is the number of sample analyses.

\section{THERMODYNAMIC MODELING}

The CPA EoS is given in terms of the pressure, as a sum of the SRK EoS and an associating contribution, in eq 2. The association term in this equation is a simpler form, but mathematically identical to the term used in SAFT. This form was proposed by Michelsen and Hendriks. ${ }^{9}$ The CPA EoS, proposed by Kontogeorgis et al., ${ }^{10,11}$ can be expressed for mixtures in terms of pressure, $P$, as:

$$
\begin{aligned}
P= & \frac{R T}{V_{\mathrm{m}}-b}-\frac{\alpha(T)}{V_{\mathrm{m}}\left(V_{\mathrm{m}}+b\right)}-\frac{1}{2} \frac{R T}{V_{\mathrm{m}}}\left(1+\rho \frac{\partial \ln g}{\partial \rho}\right) \\
& \times \sum_{i} x_{i} \sum_{\mathrm{A}_{i}}\left(1-X_{\mathrm{A}_{i}}\right)
\end{aligned}
$$

where $V_{\mathrm{m}}$ is the molar volume, while $\alpha(T)$ and $b$ are the energy and covolume parameters respectively. The key element of the association term is $X_{\mathrm{A}}$, which represents the fraction of A-sites on molecule $i$ not bonded with other active sites, while $x_{i}$ is the mole fraction of component $i$. $X_{\mathrm{A}_{i}}$ is related to the association strength $\Delta^{\mathrm{A}_{i} \mathrm{~B}_{j}}$ between two sites belonging to two different molecules, for example, site $\mathrm{A}$ on molecule $i$ and site $\mathrm{B}$ on molecule $j$, with the following expression:

$$
X_{\mathrm{A}_{i}}=\frac{1}{1+\rho \sum_{j} x_{j} \sum_{\mathrm{B}_{j}} X_{\mathrm{B}_{j}} \Delta^{\mathrm{A}_{i} \mathrm{~B}_{j}}}
$$

where the association strength $\Delta^{\mathrm{A}_{i} \mathrm{~B}_{j}}$ in CPA is expressed as:

$$
\Delta^{\mathrm{A}_{i} \mathrm{~B}_{j}}=g(\rho)\left[\exp \left(\frac{\varepsilon^{\mathrm{A}_{i} \mathrm{~B}_{j}}}{R T}\right)-1\right] b_{i j} \beta^{\mathrm{A}_{i} \mathrm{~B}_{j}}
$$

where $b_{i j}=\left(b_{i}+b_{j}\right) / 2$. The radial distribution function is defined as

$$
g(\rho)=\frac{1}{1-1.9 n^{\prime}} \quad n^{\prime}=\frac{1}{4} b \rho
$$

where $n^{\prime}$ is the reduced fluid density. Finally, the energy parameter of the EoS is given by a Soave-type temperature dependency, while $b$ is temperature-independent:

$$
\alpha(T)=a_{0}\left(1+c_{1}\left(1-\sqrt{T_{\mathrm{r}}}\right)\right)^{2}
$$

where

$$
T_{\mathrm{r}}=T / T_{\mathrm{c}}
$$

where $T_{\mathrm{c}}$ is the experimental critical temperature.

In the expression for the association strength $\Delta^{\mathrm{A}_{\mathrm{i}} \mathrm{B}_{j}}$ (eq 5) the parameters $\varepsilon^{\mathrm{A}_{\mathrm{B}} \mathrm{B}_{j}}$ and $\beta^{\mathrm{A}_{\mathrm{i}} \mathrm{B}_{j}}$ are called the association energy and the association volume, respectively. These two parameters and the three parameters, that is, $\left(\Gamma=a_{0} /(b R), b, c_{1}\right)$, are the five parameters of the CPA EoS. Usually, the three parameters of the CPA EoS (SRK-functionality) term $\left(\Gamma=a_{0} /(b R), b, c_{1}\right)$ are obtained by fitting vapor pressure and liquid density data and using the average absolute deviation $(\mathrm{AAD})$ as an objective function.

$$
\% \mathrm{AAD}=\frac{1}{n} \sum_{i}\left|\frac{X_{i}^{\mathrm{cal}}-X_{i}^{\exp }}{X_{i}^{\exp }}\right| \cdot 100
$$

where $X$ is the property and $n$ is the number of experimental data points. These parameters can also be calculated in the conventional manner from critical data and acentric factor values.

When the CPA EoS is used for mixtures, the conventional mixing rules are employed in the physical term (SRK) for the energy and covolume parameters. The geometric mean rule is used for the energy parameter $a_{i j}$. The interaction parameter $k_{i j}$ is, in the applications reported so far, the only adjustable binary parameter of CPA, unless cross association or solvation is present.

$$
\begin{aligned}
& \alpha(T)=\sum_{i} \sum_{j} x_{i} x_{j} a_{i j} \quad \text { where } \alpha_{i j}=\sqrt{\alpha_{i} \alpha_{j}}\left(1-k_{i j}\right) \\
& b=\sum_{i} x_{i} b_{i}
\end{aligned}
$$

In this work, methanethiol is considered as a nonself-associating fluid. Previously ${ }^{12}$ the phase equilibrium in terms of Henry's law constant of MM (methanethiol), EM (ethanethiol), n-PM (propane-1-thiol), n-BM (butane-1-thiol), and DMS (dimethyl sulfoxide) with water was modeled with the CPA EoS. In that work the calculations for methanethiol and ethanethiol were made using two approaches: considering thiols as inert compounds and the cross association interactions between thiols and water. The temperature dependency of the binary 
Table 2. Experimental VLE Data for the $\mathrm{CH}_{4}(1)+\mathrm{CH}_{3} \mathrm{SH}(2)$ Binary Mixture

\begin{tabular}{|c|c|c|c|c|c|c|c|c|c|c|}
\hline$T / \mathrm{K}$ & $\mathrm{P} / \mathrm{MPa}$ & $y_{\mathrm{CH}_{4}}$ & $10^{3} \cdot \sigma y_{1}$ & $y_{\mathrm{CH}_{3} \mathrm{SH}}$ & $10^{3} \cdot \sigma y_{2}$ & $P / \mathrm{MPa}$ & $x_{\mathrm{CH}_{4}}$ & $10^{3} \cdot \sigma x_{1}$ & $x_{\mathrm{CH}_{3} \mathrm{SH}}$ & $10^{3} \cdot \sigma x_{2}$ \\
\hline 304.74 & 1.201 & 0.7250 & 3.6 & 0.2750 & 2.0 & 1.209 & 0.0147 & 0.1 & 0.9853 & 0.1 \\
\hline 304.74 & 2.706 & 0.8632 & 2.1 & 0.1368 & 1.2 & 2.731 & 0.0376 & 0.4 & 0.9624 & 0.4 \\
\hline 304.75 & 3.625 & 0.8929 & 1.7 & 0.1071 & 1.0 & 3.654 & 0.0523 & 0.5 & 0.9477 & 0.5 \\
\hline 304.75 & 4.789 & 0.9116 & 1.5 & 0.0884 & 0.8 & 4.893 & 0.0710 & 0.7 & 0.9290 & 0.7 \\
\hline 304.75 & 5.858 & 0.9169 & 1.4 & 0.0831 & 0.8 & 5.960 & 0.0882 & 0.8 & 0.9118 & 0.8 \\
\hline 304.75 & 6.720 & 0.9186 & 1.2 & 0.0814 & 0.8 & 6.838 & 0.1020 & 0.8 & 0.8980 & 0.8 \\
\hline 304.75 & 7.776 & 0.9204 & 1.1 & 0.0796 & 0.8 & 7.924 & 0.1202 & 0.9 & 0.8798 & 0.8 \\
\hline 333.70 & 1.106 & 0.4720 & 2.1 & 0.5280 & 2.1 & 1.116 & 0.0091 & 0.2 & 0.9898 & 0.2 \\
\hline 333.70 & 1.990 & 0.6409 & 2.8 & 0.3591 & 1.5 & 2.013 & 0.0214 & 0.5 & 0.9786 & 0.5 \\
\hline 333.70 & 3.014 & 0.7447 & 2.2 & 0.2553 & 1.2 & 3.048 & 0.0371 & 0.6 & 0.9629 & 0.6 \\
\hline 333.70 & 4.086 & 0.8018 & 1.9 & 0.1982 & 1.0 & 4.136 & 0.0550 & 0.9 & 0.9450 & 0.9 \\
\hline 333.70 & 5.278 & 0.8371 & 1.8 & 0.1629 & 1.0 & 5.347 & 0.0738 & 1.0 & 0.9251 & 1.0 \\
\hline 333.70 & 6.473 & 0.8545 & 1.6 & 0.1455 & 1.1 & 6.588 & 0.0930 & 1.1 & 0.9070 & 1.1 \\
\hline 333.70 & 8.180 & 0.8705 & 1.5 & 0.1295 & 1.1 & 8.295 & 0.1198 & 1.2 & 0.8802 & 1.1 \\
\hline 334.28 & 8.853 & 0.8716 & 1.6 & 0.1284 & 1.1 & 8.987 & 0.1311 & 1.2 & 0.8689 & 1.1 \\
\hline 363.82 & 9.267 & 0.7319 & 5.4 & 0.2681 & 3.0 & 9.402 & 0.1331 & 0.2 & 0.8645 & 0.2 \\
\hline 363.82 & 7.906 & 0.7196 & 3.2 & 0.2804 & 1.8 & 7.975 & 0.1080 & 0.5 & 0.8900 & 0.5 \\
\hline 363.82 & 6.535 & 0.6867 & 2.6 & 0.3133 & 1.4 & 6.589 & 0.0852 & 0.7 & 0.9148 & 0.7 \\
\hline 363.82 & 4.669 & 0.6172 & 2.2 & 0.3828 & 1.2 & 4.717 & 0.0552 & 1.0 & 0.9445 & 1.0 \\
\hline 363.82 & 3.396 & 0.4995 & 2.1 & 0.5005 & 1.1 & 3.416 & 0.0338 & 1.2 & 0.9652 & 1.2 \\
\hline 363.82 & 1.213 & 0.0250 & 1.8 & 0.9750 & 1.2 & 1.213 & 0.0007 & 1.3 & 0.9994 & 1.2 \\
\hline
\end{tabular}

Table 3. Experimental VLE Data for the $\mathrm{N}_{2}(1)+\mathrm{CH}_{3} \mathrm{SH}$ (2) Binary Mixture

\begin{tabular}{|c|c|c|c|c|c|c|c|c|c|c|}
\hline$T / \mathrm{K}$ & $\mathrm{P} / \mathrm{MPa}$ & $y_{\mathrm{N}_{2}}$ & $10^{3} \cdot \sigma y_{1}$ & $y_{\mathrm{CH}_{3} \mathrm{SH}}$ & $10^{3} \cdot \sigma y_{2}$ & $\mathrm{P} / \mathrm{MPa}$ & $x_{\mathrm{N}_{2}}$ & $10^{3} \cdot \sigma x_{1}$ & $x_{\mathrm{CH}_{3} \mathrm{SH}}$ & $10^{3} \cdot \sigma x_{2}$ \\
\hline 304.07 & 1.091 & 0.7139 & 3.7 & 0.2861 & 6.1 & 1.111 & 0.0025 & 0.1 & 0.9975 & 0.1 \\
\hline 304.07 & 2.267 & 0.8535 & 2.3 & 0.1465 & 3.8 & 2.317 & 0.0063 & 0.2 & 0.9937 & 0.2 \\
\hline 304.07 & 3.661 & 0.9015 & 1.6 & 0.0985 & 2.7 & 3.734 & 0.0104 & 0.3 & 0.9896 & 0.3 \\
\hline 304.07 & 6.394 & 0.9343 & 1.7 & 0.0657 & 2.4 & 6.490 & 0.0186 & 0.3 & 0.9814 & 0.3 \\
\hline 333.78 & 1.285 & 0.4313 & 4.4 & 0.5687 & 7.4 & 1.307 & 0.0031 & 0.1 & 0.9969 & 0.1 \\
\hline 333.78 & 2.434 & 0.6611 & 2.7 & 0.3389 & 4.5 & 2.468 & 0.0071 & 0.2 & 0.9929 & 0.2 \\
\hline 333.78 & 3.957 & 0.7693 & 1.9 & 0.2307 & 3.2 & 4.035 & 0.0127 & 0.4 & 0.9873 & 0.4 \\
\hline 333.78 & 5.511 & 0.8244 & 2.1 & 0.1756 & 2.9 & 5.597 & 0.0188 & 0.4 & 0.9812 & 0.4 \\
\hline 333.78 & 6.637 & 0.8500 & 2.2 & 0.15 & 3.0 & 6.736 & 0.0231 & 0.4 & 0.9769 & 0.4 \\
\hline 363.64 & 2.622 & 0.3981 & 4.4 & 0.6019 & 7.4 & 2.665 & 0.0075 & 0.1 & 0.9925 & 0.1 \\
\hline 363.64 & 4.219 & 0.5976 & 2.7 & 0.4024 & 4.5 & 4.197 & 0.0144 & 0.2 & 0.9856 & 0.2 \\
\hline 363.64 & 4.392 & 0.6012 & 1.9 & 0.3988 & 3.2 & 4.328 & 0.0148 & 0.4 & 0.9852 & 0.4 \\
\hline 363.64 & 6.518 & 0.7027 & 2.1 & 0.2973 & 2.9 & 6.667 & 0.0273 & 0.4 & 0.9727 & 0.4 \\
\hline 363.64 & 8.138 & 0.7415 & 2.2 & 0.2585 & 3.0 & 8.308 & 0.0373 & 0.4 & 0.9627 & 0.4 \\
\hline
\end{tabular}

interaction parameter $\left(k_{i j}\right)$ and the solvation effect involved in the association volume $\left(\beta_{\text {cross }}\right)$ was accentuated in MM (methanethiol) + water, EM (ethanethiol) + water, and DMS (dimethyl sulfoxide) + water systems. As no hydrogen bonding is present in methanethiol $+\mathrm{CH}_{4}$, methanethiol $+\mathrm{N}_{2}$ or methanethiol $+\mathrm{CO}_{2}$, no association and no solvation effect have been considered in this work.

\section{RESULTS AND DISCUSSION}

The obtained new vapor-liquid equilibrium (VLE) data for the $\mathrm{CH}_{3} \mathrm{SH}+\mathrm{CH}_{4}, \mathrm{CH}_{3} \mathrm{SH}+\mathrm{N}_{2}$, and $\mathrm{CH}_{3} \mathrm{SH}+\mathrm{CO}_{2}$ binary systems at three different temperatures, $(304,334$, and 364) $\mathrm{K}$, and at pressures varying from ( 1 to 8$) \mathrm{MPa}$ are shown in Tables 2, 3, and 4, respectively. The accuracy of the measuring procedure has been previously discussed in literature. ${ }^{4,8}$ The objective was to provide experimental VLE data of the methanethiol with $\mathrm{CH}_{4}, \mathrm{~N}_{2}$, and $\mathrm{CO}_{2}$ because the solubility data of methanethiol are in general quite scarce over a large temperature and pressure range. Privat et al. ${ }^{5}$ have been working for the extension of PPR-78 model to the mercaptan containing systems. They could not extend the PPR-78 model for thiols due to the unavailability of the experimental data for (mercaptan $+\mathrm{CO}_{2}$ ) and (mercaptan $+\mathrm{N}_{2}$ ). The authors also report the modeling of limited solubility data $(P T x)$ of $\mathrm{CH}_{3} \mathrm{SH}+$ $\mathrm{CH}_{4}$ available in the open literature. ${ }^{13}$ To the best of our knowledge, prior to this study there were no experimental data for the solubility of methanethiol with $\mathrm{N}_{2}$ and $\mathrm{CO}_{2}$ at high pressures and different temperatures.

The CPA parameters, that is, $b, \Gamma=a_{0} /(R b)$, and $c_{1}$, have been fitted to experimental vapor pressure and liquid density data as shown in Table 5. The VLE data of binary systems, which consist of methanethiol $(\mathrm{MM})+$ methane $\left(\mathrm{CH}_{4}\right)$, methanethiol $(\mathrm{MM})+$ nitrogen $\left(\mathrm{N}_{2}\right)$, and methanethiol $(\mathrm{MM})+$ carbon dioxide $\left(\mathrm{CO}_{2}\right)$ at different temperatures and pressures, were successfully modeled with CPA using small binary interaction parameters $\left(k_{i j}\right)$ as shown in Figures $2 \mathrm{a}, 3$, and 4 . The $(P T x)$ data of methanethiol $(\mathrm{MM})+$ methane $\left(\mathrm{CH}_{4}\right)$ between (258 and 293) $\mathrm{K}^{13}$ have also been successfully modeled with CPA and plotted in Figure $2 \mathrm{~b}$. 
Table 4. Experimental VLE Data for the $\mathrm{CO}_{2}(1)+\mathrm{CH}_{3} \mathrm{SH}$ (2) Binary Mixture

\begin{tabular}{|c|c|c|c|c|c|c|c|c|c|c|}
\hline$T / \mathrm{K}$ & $\mathrm{P} / \mathrm{MPa}$ & $y_{\mathrm{CO}_{2}}$ & $10^{3} \cdot \sigma y_{1}$ & $y_{\mathrm{CH}_{3} \mathrm{SH}}$ & $10^{3} \cdot \sigma y_{2}$ & $P / \mathrm{MPa}$ & $x_{\mathrm{CO}_{2}}$ & $10^{3} \cdot \sigma x_{1}$ & $x_{\mathrm{CH}_{3} \mathrm{SH}}$ & $10^{3} \cdot \sigma x_{2}$ \\
\hline 303.80 & 1.011 & 0.6322 & 4.2 & 0.3678 & 9.3 & 1.015 & 0.0712 & 2.6 & 0.9286 & 2.1 \\
\hline 303.80 & 1.918 & 0.8030 & 4.2 & 0.1970 & 9.4 & 1.929 & 0.1722 & 2.7 & 0.8279 & 2.4 \\
\hline 303.80 & 3.290 & 0.8610 & 4.3 & 0.1390 & 9.5 & 3.300 & 0.3725 & 2.7 & 0.6284 & 2.6 \\
\hline 333.40 & 1.472 & 0.3887 & 3.8 & 0.6113 & 8.4 & 1.451 & 0.0410 & 2.8 & 0.9590 & 2.7 \\
\hline 333.40 & 2.512 & 0.6076 & 3.9 & 0.3924 & 8.5 & 2.523 & 0.1259 & 2.5 & 0.8739 & 2.1 \\
\hline 333.40 & 4.448 & 0.6134 & 4.1 & 0.3866 & 8.7 & 4.508 & 0.2921 & 2.6 & 0.7078 & 2.0 \\
\hline 363.48 & 7.525 & 0.6655 & 4.0 & 0.3345 & 8.9 & 7.513 & 0.3661 & 9.3 & 0.6347 & 9.3 \\
\hline 363.48 & 4.915 & 0.5874 & 4.2 & 0.4126 & 9.3 & 4.959 & 0.2183 & 9.7 & 0.8065 & 9.7 \\
\hline 363.48 & 2.444 & 0.3667 & 4.4 & 0.6333 & 9.8 & 2.472 & 0.0629 & 10.2 & 0.9369 & 10.2 \\
\hline
\end{tabular}

Table 5. CPA Pure Component Parameters Used and Estimated in This Work ${ }^{a}$

\begin{tabular}{|c|c|c|c|c|c|c|}
\hline & $T_{\mathrm{c}}^{14}$ & $b$ & $\Gamma=a_{0} / b R$ & & & \\
\hline component & $\mathrm{K}$ & $\mathrm{L} \cdot \mathrm{mor}^{-1}$ & K & $c_{1}$ & $\% \mathrm{AAD}$ in $P^{\mathrm{Sat}}$ & $\% \mathrm{AAD}$ in $\rho^{\text {liq }}$ \\
\hline methanethiol (MM) & 469.95 & 0.0437 & 2266.27 & 0.8007 & 0.69 & 0.47 \\
\hline methane $\left(\mathrm{CH}_{4}\right)^{15}$ & 190.6 & 0.0291 & 959.1 & 0.4471 & 0.35 & 1.97 \\
\hline carbon dioxide $\left(\mathrm{CO}_{2}\right)^{15}$ & 304.21 & 0.0272 & 1551.2 & 0.7602 & 0.20 & 0.80 \\
\hline nitrogen $\left(\mathrm{N}_{2}\right)$ & 615.02 & 0.02605 & 633.44 & 0.4985 & 0.50 & 2.1 \\
\hline
\end{tabular}

${ }^{a}$ Average absolute deviation (AAD) is defined as $\% \mathrm{AAD}=1 / n \sum_{i} \mid X_{i}^{\text {cal }}-X_{i}^{\text {exp }} / X_{i}^{\text {exp }} \cdot 100$ where $X$ stands for $P^{\text {Sat }}$ or $\rho^{\text {liq }}$ and $n$ is the number of experimental data points.

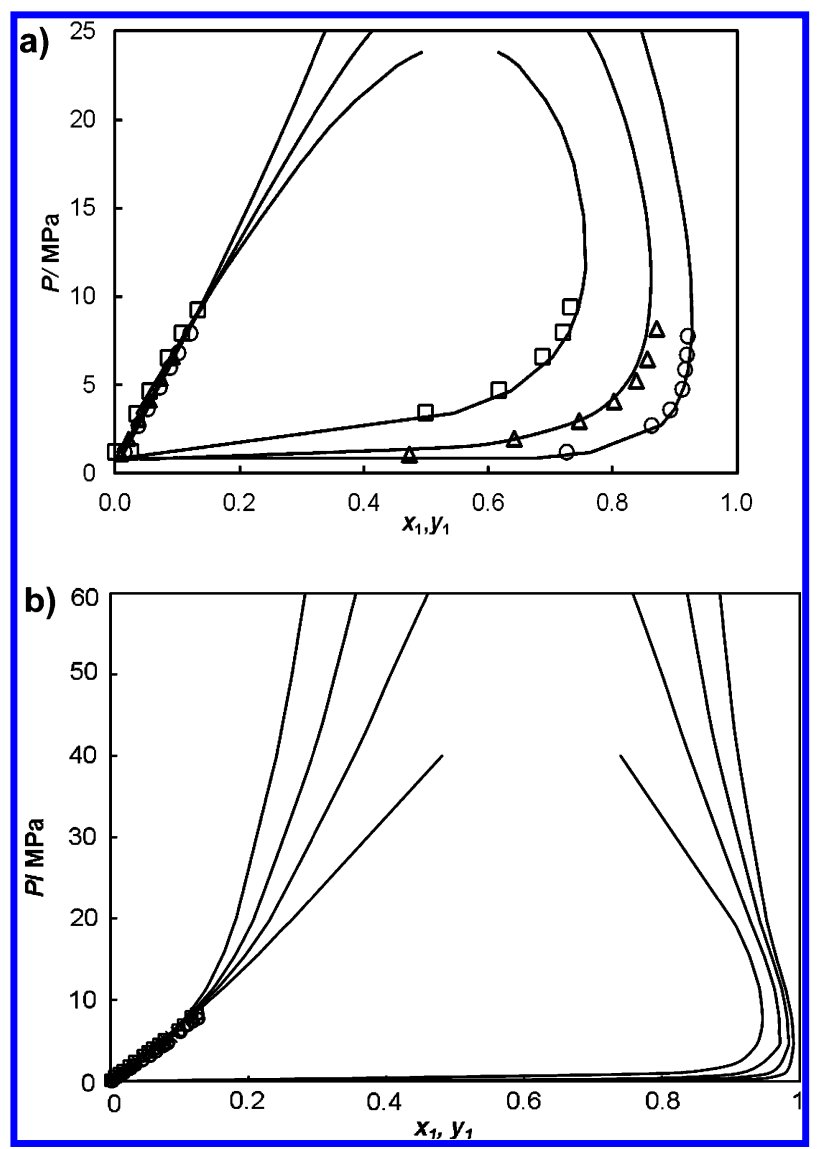

Figure 2. Pxy diagram of the methane (1) $\left(\mathrm{CH}_{4}\right)+$ methanethiol (2) (MM) binary system at (a) $\mathrm{O}, 304 \mathrm{~K} ; \triangle, 334 \mathrm{~K}$, and $\square, 364 \mathrm{~K}$; (b) $\mathrm{O}$, $293 \mathrm{~K} ; \triangle, 273 \mathrm{~K} ; \diamond, 243 \mathrm{~K}$, and $\square, 258 \mathrm{~K}$; solid lines: CPA EoS with $k_{i j}=0.079$.

The proposed binary interaction parameters for methanethiol $(\mathrm{MM})+$ methane $\left(\mathrm{CH}_{4}\right)$, methanethiol $(\mathrm{MM})+$ nitrogen $\left(\mathrm{N}_{2}\right)$, and methanethiol $(\mathrm{MM})+$ carbon dioxide $\left(\mathrm{CO}_{2}\right)$ systems are

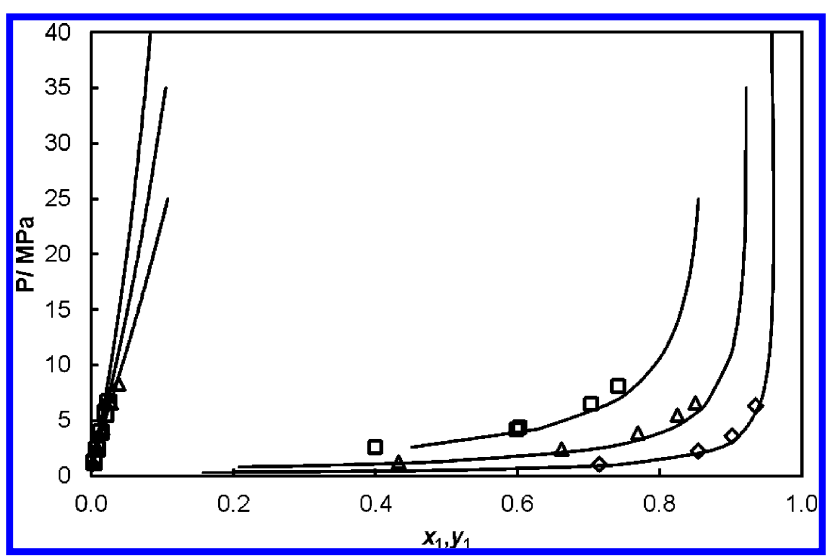

Figure 3. Pxy diagram of the nitrogen (1) $\left(\mathrm{N}_{2}\right)+$ methanethiol (2) (MM) binary system at $\diamond, 304 \mathrm{~K} ; \triangle, 334 \mathrm{~K}$, and $\square, 364 \mathrm{~K}$, solid lines: CPA EoS with $k_{i j}=0.159$.

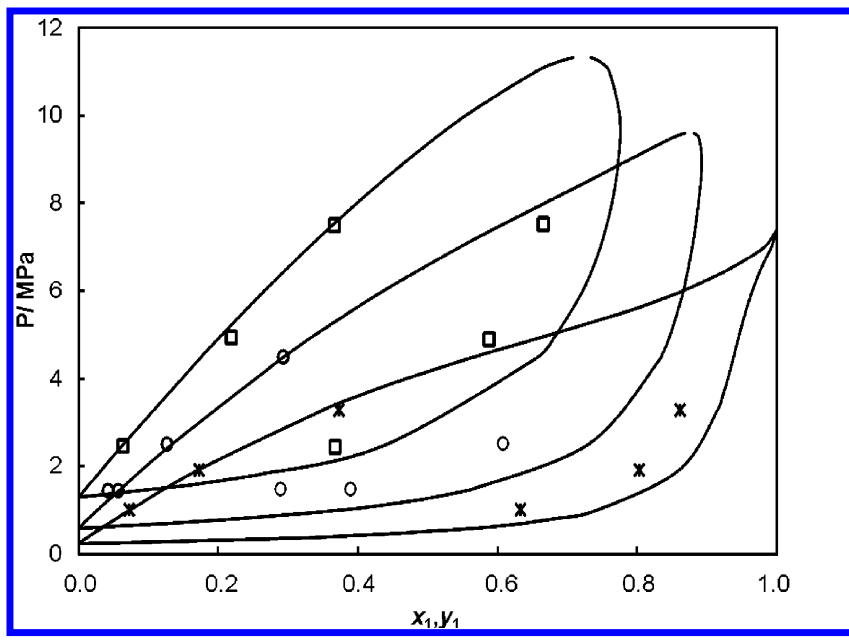

Figure 4. Pxy diagram of the carbon dioxide (1) $\left(\mathrm{CO}_{2}\right)+$ methanethiol (2) (MM) binary system at $*, 304 \mathrm{~K}$; O, $334 \mathrm{~K}$, and $\square$, $364 \mathrm{~K}$, solid lines: CPA EoS with $k_{i j}=0.091$. 
Table 6. Binary Interaction Parameters Estimated in This Work

\begin{tabular}{lcccc}
\multicolumn{1}{c}{ binary systems } & $k_{i j}$ & $\begin{array}{c}\mathrm{MAE}^{a} \text { of } \\
x / \%\end{array}$ & $\begin{array}{c}\mathrm{MAE} \text { of } \\
y / \%\end{array}$ & $\mathrm{~T} / \mathrm{K}$ (range) \\
methane + methanethiol & 0.079 & 2.06 & 1.89 & $253-323$ \\
nitrogen + methanethiol & 0.159 & 4.01 & 3.53 & $304-373$ \\
carbon dioxide + & 0.091 & 4.24 & 9.32 & $304-383$
\end{tabular}

${ }^{a} \mathrm{MAE}=$ mean average error; $\mathrm{MAE}=1 / n \sum_{i}^{n}\left|X_{i}^{\mathrm{CPA}}-X_{i}^{\exp }\right|$ where $X$ stands for mole fraction, $x$ or $y$, and $n$ is the number of experimental data points.

reported in Table 6. As stated previously, the thiols are not considered to self-associate. ${ }^{12}$ Even with this assumption the CPA results for the binary mixtures of $\mathrm{CH}_{4}+\mathrm{CH}_{3} \mathrm{SH}$ and $\mathrm{N}_{2}+$ $\mathrm{CH}_{3} \mathrm{SH}$ without association consideration are considered to be very satisfactory.

\section{CONCLUSIONS}

New VLE data have been reported for $\mathrm{CH}_{4}+\mathrm{CH}_{3} \mathrm{SH}, \mathrm{N}_{2}+$ $\mathrm{CH}_{3} \mathrm{SH}$, and $\mathrm{CO}_{2}+\mathrm{CH}_{3} \mathrm{SH}$ with a pressure variation from (1 to 8) MPa. A static-analytic method was used for performing all of the measurements. The CPA EoS (SRK functionality) has been successfully applied for the representation of binary systems containing methanethiol. These modeling results for the binary mixtures of $\mathrm{CH}_{4}+\mathrm{CH}_{3} \mathrm{SH}, \mathrm{N}_{2}+$ $\mathrm{CH}_{3} \mathrm{SH}$, and $\mathrm{CO}_{2}+\mathrm{CH}_{3} \mathrm{SH}$ without association consideration are satisfactory. For the system $\mathrm{CO}_{2}+\mathrm{CH}_{3} \mathrm{SH}$, the deviations between the experimental data and CPA modeling are significant, which may be attributed to the temperature dependency or specific interaction as $\mathrm{CO}_{2}$ is a particular molecule.

\section{AUTHOR INFORMATION}

\section{Corresponding Author}

*E-mail: gk@kt.dtu.dk. Phone: +45 45252859. Fax: +45 45882258.

\section{Funding}

The authors gratefully acknowledge the Danish Council for Independent Research (Technology and Production Sciences) for the Postdoctoral research grant to J.A.A. at CERE, DTU Chemical Engineering. The authors wish also to thank Statoil and Gassco (Norway), BP (UK, USA), TOTAL (France), DONG Energy, and Mærsk Oil and Gas (Denmark) for supporting the CPA-EoS part of this work as part of the CHIGP project (Chemicals in Gas Processing).

\section{Notes}

The authors declare no competing financial interest.

\section{REFERENCES}

(1) Zudkevitch, D.; Wilson G. M. Phase Equilibria in Solutions Methanethiol and Light Hydrocarbons, 53rd GPA Annual Convention, Denver, CO, March 25-27, 1974; pp 101-103.

(2) Carroll, J. J.; Mather, A. E. Equilibrium in Thiols + Hydrocarbons and Thiols + water a review, 8th World Congress of Chemical Engineering (WCCE8), Montréal, Canada, 2009.

(3) Huttenhuis, P. J. G.; Agrawal, N. J.; Hogendoorn, J. A.; Versteeg, G. F. Gas solubility of $\mathrm{H}_{2} \mathrm{~S}$ and $\mathrm{CO}_{2}$ in aqueous solutions of $\mathrm{N}$-methyldiethanolamine. J. Petrol. Sci. Eng. 2007, 55, 122-134.

(4) Awan, A. J. Vapor-Liquid Equilibria of Organic Sulfur SpeciesAlkanolamine Aqueous Solutions in the Presence of Acid Gases. Ph.D. Thesis, Mines Paris Tech, France, 2009.

(5) Privat, R.; Jaubert, J.-N.; Mutelet, F. Addition of the sulfhydryl group $(-\mathrm{SH})$ to the PPR78 model (predictive 1978, Peng-Robinson
EOS with temperature dependent $k_{i j}$ calculated through a group contribution method). J. Chem. Thermodyn. 2008, 40, 1331-134.

(6) Zehioua, R.; Coquelet, C.; Meniai, A. H.; Richon, D. Isothermal vapour - liquid equilibrium data of 1,1,1,2-tetrafluoroethane (R134a) + dimethylformamide (DMF) working fluids for absorption heat transformer. J. Chem Eng. Data 2009, 55, 985-988.

(7) Coquelet, C.; Chareton, A.; Richon, D. Varour-Liquid Equilibrium Measurements and Correlation of the Difluoromethane $(\mathrm{R} 32)+$ Propane (R290) + 1,1,1,2,3,3,3-Heptafluoropropane (R227ea) Ternary Mixture at Temperatures from 269.85 to $328.35 \mathrm{~K}$. Fluid Phase Equilibr 2004, 218, 209-214.

(8) Awan, A. J.; Thomsen, K.; Coquelet, C.; Fosbøl, P. L.; Richon, D. Vapor-Liquid Equilibrium Measurements and Modeling of the Propyl Mercaptan + Methane + Water System. J. Chem. Eng. Data 2010, 55, 842-846.

(9) Michelsen, M. L.; Hendriks, E. M. Physical properties from association models. Fluid Phase Equilib. 2001, 180, 165-174.

(10) Kontogeorgis, G. M.; Michelsen, M. L.; Folas, G. K.; Derawi, S.; Solms, N. V.; Stenby, E. H. Ten Years with the CPA (Cubic-PlusAssociation) Equation of State. Part-I. Pure Compounds and SelfAssociating Systems. Ind. Eng. Chem. Res. 2006, 45, 4855-4868.

(11) Kontogeorgis, G. M.; Voutsas, E. C.; Yakoumis, I. V.; Tassios, D. P. An Equation of State for Associating Fluids. Ind. Eng. Chem. Res. 1996, 35, 4310-4318.

(12) Awan, A. J.; Tsivintzelis, I.; Coquelet, C.; Richon, D.; Kontogeorgis, G. M. Phase Equilibria of Mixtures Containing Organic Sulfur Species (OSS) and Water/Hydrocarbons: VLE Measurements and Modeling Using the Cubic-Plus-Association Equation of State. Ind. Eng. Chem. Res. 2010, 49, 12718-12725.

(13) Guilbot, P.; Fischer, K.; Valtz, A.; Theveneau, P.; Baba-Ahmed, A.; Richon, D. Measurement of VLE (TPx or Tpxy data) for hydrogen sulfide + (dimethysulfide or ethylmethysulfide or carbon disulfide) and methane solubilities in (dimethylsulfide or ethylmethysulfide or methylmercaptan or ethylmercaptan). Fluid Phase Equilib. 2007, 260, 49-59.

(14) Design Institute for Physical Properties (DIPPR) Data Bank, Version 5.0.1; DIPPR: New York, 2011.

(15) Tsivintzelis, I.; Kontogeorgis, G. M.; Michelsen, M. 1.; Stenby, E. H. Modeling Phase Equilibria for Acid Gas Mixtures Using the CPA Equation of State. I. Mixtures with $\mathrm{H}_{2} \mathrm{~S}$. AIChE J. 2010, 56, 29652982.

\section{NOTE ADDED AFTER ASAP PUBLICATION}

This paper was published on February 3, 2012, with errors in Figure 1, the reference section, and throughout the text. These were corrected in the version published on February 17, 2012. 